\title{
DEVELOPMENT OF INTERACTIVE LEARNING MEDIA BASED ON COMPUTER TO IMPROVE STUDENT LEARNING MOTIVATION
}

\author{
PENGEMBANGAN MEDIA PEMBELAJARAN INTERAKTIF BERBASIS KOMPUTER \\ UNTUK MENINGKATKAN MOTIVASI BELAJAR SISWA
}

\author{
Oleh: \\ Kartika Bunga Nadhya Noor \\ Accounting Education Department Yogyakarta State University \\ bungatikaa@gmail.com
}

\author{
Mimin Nur Aisyah \\ Lecturer of Accounting Education Department Yogyakarta State University
}

\begin{abstract}
This research is aimed at developing interactive learning media for class $\mathrm{X}$ student of Accounting Major at SMK Muhammadiyah 1 Yogyakarta with basic competency materials Making Adjustment Journal Entries and also examines the feasibility of interactive learning media as well as investigate the improvement of student learning motivation after using the media. This research used Research and Development (R \& D) models and adapted ADDIE development model, which include 5 phases, namely: Analysis, Design, Development, Implementation, and Evaluation. The measurement of students learning motivation used questionnaire filled by 33 students of class X AK 1 as treatment group and 33 students of class X AK 2 as control group. The research results show that interactive learning media in Basic Accounting Subject declared as Strongly Feasible category with average scores of 4.5 by material expert, 4.47 by media expert, 4.35 by accounting teacher, and 4.29 by students. Based on student learning motivation analysis, the treatment group obtain an increase of $6 \%$ from $73 \%$ to $79 \%$ and control group obtain an increase of $2 \%$ from $74 \%$ to $76 \%$.
\end{abstract}

Keywords: Interactive Learning Media, Student Learning Motivation, ADDIE, Basic Accounting, Adjustment Journal Entries

\section{Abstrak}

Penelitian ini bertujuan untuk mengembangkan media pembelajaran interaktif untuk siswa kelas X kompetensi keahlian Akuntansi di SMK Muhammadiyah 1 Yogyakarta dengan materi kompetensi dasar Membuat Jurnal Penyesuaian dan juga menguji kelayakan media pembelajaran interaktif serta menyelidiki peningkatan motivasi belajar siswa sesudah penggunaan media. Penelitian ini menggunakan metode penelitian dan pengembangan atau Research and Development (R\&D) dengan model pengembangan ADDIE yaitu: 1) Analysis, 2) Design, 3) Development, 4) Implementation, dan 5) Evaluation. Pengukuran motivasi belajar siswa dilakukan dengan menggunakan angket terhadap 33 siswa kelas $X A K 1$ sebagai kelompok perlakuan dan kelas X AK 2 sebagai kelas control. Hasil penelitian menunjukkan bahwa media pembelajaran interaktif pada mata pelajaran Akuntansi Dasar dinyatakan Sangat Layak dengan skor rata-rata 4,5 oleh ahli materi, 4,47 oleh ahli media, 4,35 oleh guru akuntansi, dan 4,29 oleh siswa. Berdasarkan analisis motivasi belajar siswa, Motivasi belajar kelompok perlakuan meningkat sebesar 6\% dari $73 \%$ menjadi $79 \%$ sedangkan kelompok kontrol meningkat sebesar $2 \%$ dari $74 \%$ menjadi $76 \%$.

Kata Kunci: Media Pembelajaran Interaktif, Motivasi Belajar, ADDIE, Akuntansi Dasar, Jurnal Penyesuaian 


\section{INTRODUCTION}

The advancement of technology and information in the era of globalization is inevitable and become a challenge that must be faced by every nation, including Indonesia. It occurs in every fields, from social, economic, cultural, and educational. Indonesia must have a good preparation in order to compete with the other countries. According to Michael Porter (1990: 35), there are four factors affecting the competitiveness of a nation, namely: (1) Strategy, structure, and level of corporate competition (2) Resources in a country both Human Resources and Natural Resources (3) Domestic demand and (4) The existence of an industry. Human resources is one of the main factors that affect the competitiveness of a nation. Education play an important role for obtaining high quality of human resources.

Technology and information provides great effects on education. The development of computer technology opens a very wide opportunity for educators to use it well (Efendi, 2014:121). It is clear that the use of technology in the educational process is very beneficial for educators and learners (Astriana, 2017:147). This development brings a positive impacts on the learning process which becomes more interesting, easy to do everywhere and everytime, and also easier to achieve the learning objectives (Risnawati, 2015: 1). Learning objectives according to Sukandi (2001: 11) is to make changes in behavior. The change can be expressed in skill, habit, attitude, understanding, knowledge, or acceptance and reward. In achieving this learning objectives, students must have motivation to learn and willingness to follow the learning process. According to Sanjaya (2013: 135), motivation is a change of energy in a person who is characterized by the emergence of feelings and reactions to achieve goals. Motivation is a very important aspect, because without motivation learners will not have the willingness to learn.
The use of learning media can help to improve the motivation of students to learn. The learning media is anything that can be used to transmit messages from the sender to the recipients to stimulate the students' thoughts, feelings, concerns and interests in such a way that the learning process takes place (Sardiman, 2011:7). Thus, learning media can attract interest and attention of students in the learning process to improve student learning motivation.

Based on observation at SMK Muhammadiyah 1 Yogyakarta, the school has many facilities to support learning activities, such as LCD projector and computer laboratory. Teachers as facilitators in the learning process should have the ability to utilize technology as a learning media. However the teacher did not optimally utilize the facilities to create learning media that can stimulate students learning motivation. Instead, they still used conventional methods by using whiteboards and textbooks.

Basic Accounting subject is one of the subjects that must be mastered by students of Vocational High School (SMK) majoring in accounting. Basic accounting subject is studied by students in $10^{\text {th }}$ grade. This subject is very important, since it provides the basic knowledge of accounting. When a student is not able to understand the fundamental of accounting they will face greater problem in the next level. It might also create a feeling that accounting is a difficult subject and demotivate students to learn accounting further. Therefore, the materials that exist in basic accounting subject should be presented clearly and interesting in order to increase student interest and motivation. From a short interview with the teacher, there is one basic competence $(\mathrm{KD})$ that is challenging for students, namely adjustment journal. Students often feel confused and experience difficulty in understanding the material, so the teacher must put extra efforts to explain it. 
Based on the observations in class X AK 1 SMK Muhammadiyah 1 Yogyakarta at Basic Accounting subject, it is found that student's learning motivation was still very low. It can be seen from more than $50 \%$ of the students in the class were still busy talking to their friends although the teacher has opened and started the lesson. Students were also not discipline, as some students came late to the class. In addition, there were many students who got bored, felt sleepy and yawned, leaned their head on the table, and did not open the textbook. From brief interview to the students of class X AK 1, it was found that 4 out of 5 students felt that the learning media used by the teacher was not interesting, so they felt bored. The condition suggested that an interesting and fun media is necessary to improve student's learning motivation. The existence of learning media in the classroom activities will increase the interaction among teacher and students to drive an optimal learning process.

Sudjana and Rivai explain the benefits of learning media in the learning process, such as: (1) Learning process will attract the students attention so it can grow the learning motivation, (2) Learning materials will be presented more clearly so that it can be better understood by students and the students enable to master and achieve the learning objectives, (3) The teaching method will be vary, not merely verbal communication through the words of the teacher, (4) Students can learn more because they are not only listen to teachers but also do other activities such as observing, performing, demonstrating, playing, and others (Arsyad, 2011: 25). Therefore, interesting and interactive learning media can help the learning activities and also achieve the learning objectives.

Interesting and interactive learning media can be made by using computer-based media. Sihotang (2017:27) stated that computer based learning is the learning which uses computer software in its implementation. According to Warsita (2008: 137) there are several advantages of computer-based learning media, such as the ability to integrate components of color, music and animated graphics. Thus, the computer is able to convey information and knowledge with a high level of realism. Furthermore, the memory capacity possessed by the computer allows users to redisplay the learning results that have been achieved previously.

There are many software or computer-based applications that can be used to create interactive learning media, one of them is Lectora Inspire software. Lectora Inspire software can display moving images, music, and has unique template. It also provides a variety of evaluation or simple test facilities, such as multiple choice, right/wrong, and matching questions. The final product of Lectora is using an .exe format so that users can use the learning media without the need for internet connection or install Lectora Inspire software first.

From the problems that have been described above, it can be concluded that the absence of the computer based learning media for basic accounting subjects in SMK Muhammadiyah 1 Yogyakarta create low students' motivation in clasroom learning activities. With the advantages of computerbased learning media using Lectora Inspire software, the researcher develop an interactive learning media using Lector Inspire software on basic accounting subjects to improve the learning motivation of class $\mathrm{X}$ AK 1 students in SMK Muhammadiyah 1 Yogyakarta.

\section{RESEARCH METHODS Type of Research}

This research used method of research and development (R \& D). According to Sukmadinata (2009: 164), research and development is a process or steps to develop a new product or improve existing products, which can be accounted for. Products are not always shaped objects or hardware, such as books, module, learning tools in the classroom or in 
the laboratory, but it can also software. Such software can be used for: (1) Data processing (2) Learning in the classroom, library or laboratory, and (3) Models of education, learning, training, evaluation, management, and so on.

This research used ADDIE model developed by Dick and Carey. It has been modified to produce a simple development model for beginner researcher.

\section{Time and Place of Research}

The research was conducted in SMK Muhammadiyah 1 Yogyakarta in Jalan Nitikan, Yogyakarta from January to April 2018.

\section{Subject of The Research}

The main subjects of this study were 30 students of class XI AK 1 as subject of media trials, 33 students of class $\mathrm{X}$ AK 1 as treatment group, and 33 students of class $\mathrm{X}$ AK 2 as control class. The next subjects are material experts, media experts, and accounting learning practitioners.

\section{Research Procedures}

The procedure of this research adapted ADDIE development model that consists of five stages, namely: analysis, design, development, implementation, and evaluation. The development procedure of developing interactive learning media using Lectora Inspire Software is conducted in accordance with the adaptation of ADDIE development model.

a) Analysis

At this stage, the purpose of the product development is to make learning more fun and to help the students to understand the concept of basic accounting easier and work on it independently. A software of interactive media should be easy to use and has animations as well as video tutorials in order to encourage students to learn independently.

The researcher conducted an analysis of the accounting subjects syllaby, especially in basic accounting material at the second semester for class $X$ Accounting student of SMK Muhammadiyah 1 Yogyakarta. This analysis was aimed at identifying and defining basic competencies and the number of indicators developed in the basic competence.

b) Design

Based on the previous analysis, the process move to the design phase which include: (1) Making learning scenarios that explain the description of the material to be displayed and an overview of student activity (2) Preparation of the overall product design (storyboard) to understand the relationship of each product section and the layout (3) Collecting the design objects of interactive media such as background, pictures, sound effects, and buttons that would be processed in Lectora Inspire Software (4) Arrange the assessment instruments in the form of questionnaires provided for the material expert, media expert, accounting teacher, and students as the target of implementation (5) Develop learning motivation instrument to measure students' learning motivation before and after the use of the interactive learning media and then test the instrument's validity and reliability.

c) Development

The development stage has the following activities:

1) Develop interactive media using Software Lectora Inspire. All the components which have been prepared in the design stage arranged into a single complete product.

2) Product validation I, the initial product was validated by material expert and media expert.

3) Product revision I, the product was revised based on feedback and suggestions by material expert and 
media expert.

4) Product validation II, the product was validated by accounting teacher at SMK Muhammadiyah 1 Yogyakarta.

5) Product revision II, the product was revised based on feedback and suggestions provided by accounting teacher. The final version was used in the implementation stage.

d) Implementation

At the implementation stage the product was tested to the 30 students of class XI AK 1 SMK Muhammadiyah 1 Yogyakarta (non-treatment group and non-control group). Students' responses about the media were also examined.

e) Evaluation

At this stage, the activities included: (1) Analyzing data obtained from validation conducted by material expert, media expert, and accounting teacher (2) Analyzing data obtained from the students to know the students' response to the media (3) The final product after validation and revision in the previous stage (4) The final product will be implemented in the learning process in class $\mathrm{X} \mathrm{AK} 1$ as treatment class to know the improvement of students' learning motivation.

\section{Data and Data Technique Analysis}

a) Data

Data collected in this research includes qualitative and quantitative data, namely: (1) Qualitative data is obtained from criticism and suggestion by material expert, media expert, and accounting learning practitioner (2) Quantitative data is score obtained in this research from validation stage, students' responses data, and the improvement of the students' learning motivation. The score obtained will be converted into numeric form. b) Data Technique Analysis

The collected data analyzed to determine the judgments or opinions of the product and improvement student learning motivation. Data obtained from the material expert, media expert, accounting teacher, and students in the form of media feasibility data as follows:

1) Transform qualitative into quantitative

Table 1. Scoring Rules with Likert

\begin{tabular}{|l|c|}
\hline \multicolumn{1}{|c|}{ Classification } & Score \\
\hline Very Good & 5 \\
\hline Good & 4 \\
\hline Enough & 3 \\
\hline Poor & 2 \\
\hline Very Poor & 1 \\
\hline
\end{tabular}

Source: Sugiyono (2015:135)

2) Calculate the average score of each aspect using the following formula:

$$
\bar{X}=\frac{\Sigma X}{N}
$$

Descriptions:

$$
\begin{array}{ll}
\bar{X} & =\text { Average score } \\
\Sigma X & =\text { Total score } \\
\mathrm{N} & =\text { Item Subject }
\end{array}
$$

3) Interpret qualitative average value of each aspect and all aspects by using the following criteria:

Table 2. Converting Qualitative Data to Quantitative Data

\begin{tabular}{|l|l|}
\hline Interval Score & \multicolumn{1}{|c|}{ Score } \\
\hline $4.21<\mathrm{X}<5$ & Strongly Feasible \\
\hline $3.41<\mathrm{X}<4.2$ & Feasible \\
\hline $2.61<\mathrm{X}<$ & Moderately \\
3.4 & Feasible \\
\hline $1,82<\mathrm{X}<$ & Unfeasible \\
2.60 & \\
\hline $\mathrm{X} \leq 1,8$ & Strongly \\
\hline
\end{tabular}

Data obtained from the measurement of students learning improvement was analyzed as follows: 
1) Analyze quantitative data scores descriptively with a conversion table values as follows:

Table 3. Criteria Scoring Items on Motivation

Questionnaire

\begin{tabular}{|l|c|c|}
\hline \multirow{2}{*}{ Criteria } & \multicolumn{2}{|c|}{ Score } \\
\cline { 2 - 3 } & Positive & Negative \\
\hline $\begin{array}{l}\text { Strongly } \\
\text { Agree }\end{array}$ & 5 & 1 \\
\hline Agree & 4 & 2 \\
\hline $\begin{array}{l}\text { Less } \\
\text { Agree }\end{array}$ & 3 & 3 \\
\hline Disagree & 2 & 4 \\
\hline $\begin{array}{l}\text { Strongly } \\
\text { Disagree }\end{array}$ & 1 & 5 \\
\hline
\end{tabular}

2) Calculate the scores for each aspect of motivation

3) Calculate the scores of the student motivation every aspect

4) Calculate the difference in improvement learning motivation of each student in treatment class (X AK 1) and control class (X AK 2)

5) Test the improvement of students' learning motivation by using different test paired sample t test and independent sample $t$ test with formula:

$$
t=\frac{\bar{D}}{\left(\frac{S D}{\sqrt{N}}\right)}
$$

$\mathrm{D}=$ The average margin scores

$\mathrm{SD}=$ Standard Deviation of $\mathrm{D}$

$\mathrm{N}=$ Total Pairs

6) Test the proposed hypothesis. There are 2 hypothesis in this research:

Ha: The use of media improves the students' learning motivation

H0: The use of media does not improve students' learning motivation
Ha: There is significant difference on the improvement of students' learning motivation between treatment group and control group.

H0: There is no significant difference on the improvement of students' learning motivation between treatment group and control group.

\section{RESULT OF THE RESEARCH AND DISCUSSION \\ Development of Interactive Learning Media}

The implementation of development research is conducted by five stages with the following details:

1. Analysis Stage. The activities in this stages include: subject analysis, syllaby analysis, and purpose formulation.

2. Design Stage. The activities in this stage include: material arrangement, storyboard, lesson plans, questionnaire development, and questionnaire testing.

3. Development stage. The activities in this stage include: developing interactive learning media, experts validation, product revision I, accounting teacher validation, and product revision II.

4. Implementation stage, the activities in this stage include: Media trials and examine students response

5. Evaluation stage, the activity in this stage is measurement students learning motivation in class X AK 1 and $\mathrm{X}$ AK 2

\section{Feasibility of Interactive Learning Media}

Feasibility of interactive learning media was known through the stages of validation by experts.

1. Material Expert 
Table 4. Result Validation by Material Expert

\begin{tabular}{|l|l|c|c|c|}
\hline No & $\begin{array}{l}\text { Feasibility } \\
\text { Aspects }\end{array}$ & Score & $\begin{array}{l}\text { Ave- } \\
\text { rage }\end{array}$ & Category \\
\hline 1 & Material & 81 & 4,76 & $\begin{array}{l}\text { Strongly } \\
\text { Feasible }\end{array}$ \\
\hline 2 & Language & 13 & 4,33 & $\begin{array}{l}\text { Strongly } \\
\text { Feasible }\end{array}$ \\
\hline 3 & $\begin{array}{l}\text { Learning } \\
\text { Design }\end{array}$ & 22 & 4,40 & $\begin{array}{l}\text { Strongly } \\
\text { Feasible }\end{array}$ \\
\hline \multicolumn{2}{|c|}{ Total } & 116 & 4,50 & $\begin{array}{l}\text { Strongly } \\
\text { Feasible }\end{array}$ \\
\hline
\end{tabular}

Material expert validation resulted in the average of 4.50 which means that the product developed in the "Strongly Feasible" category.

2. Media Expert

Table 5. Result Validation by Media Expert

\begin{tabular}{|c|l|c|c|l|}
\hline $\begin{array}{c}\text { N } \\
\mathbf{0}\end{array}$ & $\begin{array}{c}\text { Feasi- } \\
\text { bility } \\
\text { Aspects }\end{array}$ & Score & $\begin{array}{c}\text { Ave- } \\
\text { rage }\end{array}$ & $\begin{array}{l}\text { Cate- } \\
\text { gory }\end{array}$ \\
\hline 1 & $\begin{array}{l}\text { Software } \\
\text { Engi- } \\
\text { neering }\end{array}$ & 37 & 4,63 & $\begin{array}{l}\text { Strong- } \\
\text { ly } \\
\text { Feasi- } \\
\text { ble }\end{array}$ \\
\hline 2 & $\begin{array}{l}\text { Visual } \\
\text { Commu- } \\
\text { nication }\end{array}$ & 56 & 4,31 & $\begin{array}{l}\text { Strong- } \\
\text { ly } \\
\text { Feasi- } \\
\text { ble }\end{array}$ \\
\hline \multicolumn{2}{|c|}{ Total } & 93 & 4,47 & $\begin{array}{l}\text { Strong- } \\
\text { ly } \\
\text { Feasi- } \\
\text { ble }\end{array}$ \\
\hline
\end{tabular}

Media expert validation resulted in the average of 4.47 which means that the product developed in the "Strongly Feasible" category.
3. Accounting Teacher

Validation

by Accounting Teacher

\begin{tabular}{|c|c|c|c|c|}
\hline $\begin{array}{l}\mathbf{N} \\
\mathbf{0}\end{array}$ & $\begin{array}{l}\text { Feasi- } \\
\text { bility } \\
\text { As- } \\
\text { pects }\end{array}$ & Score & $\begin{array}{l}\text { Ave- } \\
\text { rage }\end{array}$ & $\begin{array}{l}\text { Cate- } \\
\text { gory }\end{array}$ \\
\hline 1 & $\begin{array}{l}\text { Mate- } \\
\text { rial }\end{array}$ & 46 & 4.60 & $\begin{array}{l}\text { Strong- } \\
\text { ly } \\
\text { Feasi- } \\
\text { ble }\end{array}$ \\
\hline 2 & $\begin{array}{l}\text { Langu- } \\
\text { age }\end{array}$ & 9 & 4.50 & $\begin{array}{c}\text { Strong- } \\
\text { ly } \\
\text { Feasi- } \\
\text { ble }\end{array}$ \\
\hline 3 & $\begin{array}{l}\text { Learn- } \\
\text { ing } \\
\text { Design }\end{array}$ & 20 & 4.00 & $\begin{array}{c}\text { Strong- } \\
\text { ly } \\
\text { Feasi- } \\
\text { ble }\end{array}$ \\
\hline 4 & $\begin{array}{l}\text { Softwar } \\
\mathrm{e} \\
\text { Engine } \\
\text { e-ring }\end{array}$ & 13 & 4,33 & $\begin{array}{l}\text { Strongl } \\
\text { y } \\
\text { Feasibl } \\
\text { e }\end{array}$ \\
\hline 5 & $\begin{array}{l}\text { Visual } \\
\text { Commu } \\
\text { ni- } \\
\text { cation }\end{array}$ & 26 & 4,33 & $\begin{array}{l}\text { Strongl } \\
\text { y } \\
\text { Feasibl } \\
\text { e }\end{array}$ \\
\hline & Total & 114 & 4,35 & $\begin{array}{l}\text { Strongl } \\
\text { y } \\
\text { Feasibl } \\
\text { e }\end{array}$ \\
\hline
\end{tabular}
resulted in the average of 4.35 which means that the product developed in the "Strongly Feasible" category.

\section{Students Response About Interactive Learning Media}

Media trials were conducted to 30 students of class XI AK 1 SMK Muhammadiyah 1 Yogyakarta. After students tried to use the media, students were asked to complete the questionnaire to provide a response about the learning media. In summary, the average recapitulation of student responses is as follows: 
Jurnal Pendidikan Akuntansi Indonesia, Vol. XVI, No. 2, Tahun 2018

Kartika Bunga Nadghya Noor \& Mimin Nur Aisyah

$70-81$

Table 7. Result of Students Response about Media

\begin{tabular}{|l|l|c|c|l|}
\hline No & $\begin{array}{l}\text { Feasi- } \\
\text { bility As- } \\
\text { pects }\end{array}$ & Score & $\begin{array}{l}\text { Ave- } \\
\text { rage }\end{array}$ & $\begin{array}{l}\text { Cate- } \\
\text { gory }\end{array}$ \\
\hline 1 & Material & 602 & 4.01 & Feasible \\
\hline 2 & Language & 120 & 4 & Feasible \\
\hline 3 & $\begin{array}{l}\text { Learning } \\
\text { Design }\end{array}$ & 408 & 4.53 & $\begin{array}{l}\text { Strong- } \\
\text { ly } \\
\text { Feasible }\end{array}$ \\
\hline 4 & $\begin{array}{l}\text { Software } \\
\text { Enginee- } \\
\text { ring }\end{array}$ & 409 & 4.54 & $\begin{array}{l}\text { Strong- } \\
\text { ly } \\
\text { Feasible }\end{array}$ \\
\hline 5 & $\begin{array}{l}\text { Visual } \\
\text { Commu- } \\
\text { nication }\end{array}$ & 788 & 4.38 & $\begin{array}{l}\text { Strong- } \\
\text { ly } \\
\text { Feasible }\end{array}$ \\
\hline \multicolumn{2}{|c|}{ Total } & 2327 & 4.29 & $\begin{array}{l}\text { Strongly } \\
\text { Feasible }\end{array}$ \\
\hline
\end{tabular}

Students Learning Improvement

The purpose of developing this product is to improve students learning motivation. Measurement was conducted in 2 different classes, $\mathrm{X}$ AK 1 as treatment group and class $\mathrm{X}$ AK 2 as control group which consist of 30 students in each class.

1. Class X AK 1 (Treatment Group)

Table 8. Student Learning Motivation of Class X AK 1

\begin{tabular}{|l|l|l|l|c|}
\hline No & $\begin{array}{l}\text { Learning } \\
\text { Motivation } \\
\text { Indicator }\end{array}$ & $\begin{array}{l}\text { Be- } \\
\text { fore }\end{array}$ & $\begin{array}{l}\text { Af- } \\
\text { ter }\end{array}$ & $\begin{array}{c}\text { Im- } \\
\text { prove- } \\
\text { ment }\end{array}$ \\
\hline 1 & $\begin{array}{l}\text { There is a } \\
\text { passion and } \\
\text { desire to } \\
\text { succeed }\end{array}$ & $72 \%$ & $79 \%$ & $7 \%$ \\
\hline 2 & $\begin{array}{l}\text { The drive } \\
\text { and the need } \\
\text { to learn }\end{array}$ & $72 \%$ & $78 \%$ & $6 \%$ \\
\hline 3 & $\begin{array}{l}\text { There is } \\
\text { hope and } \\
\text { ideals of the } \\
\text { future }\end{array}$ & $76 \%$ & $79 \%$ & $3 \%$ \\
\hline 4 & $\begin{array}{l}\text { There is } \\
\text { award in } \\
\text { learning }\end{array}$ & $68 \%$ & $73 \%$ & $5 \%$ \\
\hline
\end{tabular}

\begin{tabular}{|l|l|c|c|c|}
\hline No & $\begin{array}{l}\text { Learning } \\
\text { Motivation } \\
\text { Indicator }\end{array}$ & $\begin{array}{l}\text { Be- } \\
\text { fore }\end{array}$ & $\begin{array}{l}\text { Af- } \\
\text { ter }\end{array}$ & $\begin{array}{c}\text { Im- } \\
\text { prove- } \\
\text { ment }\end{array}$ \\
\hline 5 & $\begin{array}{l}\text { The interest } \\
\text { activity in } \\
\text { learning }\end{array}$ & $71 \%$ & $76 \%$ & $5 \%$ \\
\hline 6 & $\begin{array}{l}\text { There is a } \\
\text { condu-cive } \\
\text { learning } \\
\text { environ- } \\
\text { ment }\end{array}$ & $61 \%$ & $67 \%$ & $6 \%$ \\
\hline Total & $\mathbf{7 3 \%}$ & $\mathbf{7 9 \%}$ & $\mathbf{6 \%}$ \\
\hline
\end{tabular}

2. Class X AK 2 (Control Group)

Table 9. Student Learning Motivation of Class X AK 2

\begin{tabular}{|l|l|c|c|c|}
\hline No & $\begin{array}{l}\text { Learning } \\
\text { Motivation } \\
\text { Indicator }\end{array}$ & $\begin{array}{l}\text { Be- } \\
\text { fore }\end{array}$ & $\begin{array}{l}\text { Af- } \\
\text { ter }\end{array}$ & $\begin{array}{l}\text { Im- } \\
\text { prove- } \\
\text { ment }\end{array}$ \\
\hline 1 & $\begin{array}{l}\text { There is a } \\
\text { passion and } \\
\text { desire to } \\
\text { succeed }\end{array}$ & $73 \%$ & $74 \%$ & $1 \%$ \\
\hline 2 & $\begin{array}{l}\text { The drive and } \\
\text { the need to } \\
\text { learn }\end{array}$ & $72 \%$ & $75 \%$ & $3 \%$ \\
\hline 3 & $\begin{array}{l}\text { There is hope } \\
\text { and ideals of } \\
\text { the future }\end{array}$ & $76 \%$ & $77 \%$ & $1 \%$ \\
\hline 4 & $\begin{array}{l}\text { There is } \\
\text { award in } \\
\text { learning }\end{array}$ & $71 \%$ & $72 \%$ & $1 \%$ \\
\hline 5 & $\begin{array}{l}\text { The interest } \\
\text { activity in } \\
\text { learning }\end{array}$ & $71 \%$ & $74 \%$ & $3 \%$ \\
\hline 6 & $\begin{array}{l}\text { There is a } \\
\text { condu-cive } \\
\text { learning } \\
\text { environ-ment }\end{array}$ & $66 \%$ & $68 \%$ & $2 \%$ \\
\hline Total & $\mathbf{7 4 \%}$ & $\mathbf{7 6 \%}$ & $\mathbf{2 \%}$ \\
\hline
\end{tabular}

Based on the measurement of learning motivation at the beginning and the end of learning from the treatment and control group, it can be concluded that class X AK 1 as treatment group has higher improvement compared to class $\mathrm{X}$ AK 2 as control group. The treatment 
group's motivation improved by $6 \%$ from the initial motivation score of $73 \%$ and final motivation score of $79 \%$. This percentage increase is greater than the control group which only increased by $2 \%$ from the initial motivation score of $74 \%$ and the final motivation score of $76 \%$.

Researcher used Paired Sample Ttest and Independent Sample T-test to test the hypothesis that has been proposed.
1. Paired Sample T-Test in X AK 1

Hypothesis proposed in this test consist of alternative hypothesis (Ha): The use of interactive learning media will increase student's learning motivation, so that null hypothesis (H0): The use of interactive learning media does not improve student's learning motivation. The following is the result of recapitulation of paired sample test of treatment group:

Table 10. Paired Sample T-Test in Treatment Group

\begin{tabular}{|c|c|c|c|c|c|c|}
\hline & \multicolumn{2}{|c|}{ Mean } & Correlation & Sig & T & $\begin{array}{c}\text { Sig-2 } \\
\text { tailed }\end{array}$ \\
\hline $\begin{array}{c}\text { Pair } \\
1\end{array}$ & $\begin{array}{c}\text { Before } \\
77.09\end{array}$ & $\begin{array}{c}\text { After } \\
83.39\end{array}$ & .532 & .001 & 8.89 & .000 \\
\hline
\end{tabular}

The result of paired sample statistics table shows the average calculation result of the total initial motivation score is 77.09 while the final motivation score is 83.39 . The paired correlation table shows that the correlation between two variables is 0.532 , with sig 0.001 . That is, the correlation between the total score of motivation before and after the use of Interactive Learning Media is accurate and significant. If the probability value or Sig. (2-tailed) $<0,05$ then hypothesis $\mathrm{H} 0$ is rejected and $\mathrm{Ha}$ accepted. In the t-test test obtained Sig. (2-tailed) $=0,000$ $<0,05$ then indicates that $\mathrm{HO}$ is rejected and Ha accepted. This shows the use of interactive learning media improves students' motivation score.

2. Paired Sample T-Test in $X$ AK 2

Hypothesis proposed in this test consist of alternative hypothesis (Ha): The use of learning media will improve students learning motivation, so that null hypothesis (H0): The use of learning media does not increase students learning motivation. The following is the result of a paired sample sample recapitulation test:

Table 11. Paired Sample T-Test in Control Group

\begin{tabular}{|c|c|c|c|c|c|c|}
\hline & \multicolumn{2}{|c|}{ Mean } & Correlation & Sig & T & Sig-2 tailed \\
\hline Pair & Before & After & .870 & .000 & 3.456 & .002 \\
1 & 77.54 & 79.84 & & & & \\
\hline
\end{tabular}

The result of paired sample statistics table shows the average calculation result of the total initial motivation score is 77.54 while the final motivation score is 79.84 . The paired correlation table shows that the correlation between the two variables is 0.870 , with sig 0,000 .
That is, the correlation between the total score of motivation before and after the use of learning media is accurate and significant. If the probability value or Sig. (2-tailed) $<0,05$ then hypothesis $\mathrm{HO}$ is rejected and $\mathrm{Ha}$ accepted. In the t-test test obtained Sig. (2-tailed) $=0.002$ 
$<0.05$ then indicates that $\mathrm{H} 0$ is rejected and $\mathrm{Ha}$ is accepted. This shows that the use of learning media is able to improve students' motivation score.

3. Independent Sample T-Test

Independent $t$ test is done by comparing the increase of learning motivation score of class $\mathrm{X}$ AK 1 as treatment group and class $\mathrm{X}$ AK 2 as control group. The hypothesis proposed in this test consist of alternative Hypothesis ( $\mathrm{Ha}$ ): There is a significant difference improvement of student learning motivation between class $\mathrm{X}$ AK 1 as treatment group with class $\mathrm{X}$ AK 2 as control group, so that null hypothesis $(\mathrm{H} 0)$ : There is no significant difference improvement of student learning motivation between class X AK 1 as treatment group with class $\mathrm{X}$ AK 2 as control group. The following is the result of independent $t$ test recapitulation:

Table 12. Independent Sample TTest between Treatment and Control Group

\begin{tabular}{|l|c|c|c|}
\hline Group & $\begin{array}{l}\text { Tota } \\
\text { l }\end{array}$ & $\begin{array}{l}\text { Averag } \\
\text { e }\end{array}$ & $\begin{array}{l}\text { Sig. (2- } \\
\text { tailed) }\end{array}$ \\
\hline $\begin{array}{l}\text { Treat- } \\
\text { ment } \\
\text { (X AK } \\
\text { 1) }\end{array}$ & 33 & 6,0000 & .000 \\
\hline $\begin{array}{l}\text { Control } \\
\text { (X AK } \\
\text { 2) }\end{array}$ & 33 & 1,9091 & .000 \\
\hline
\end{tabular}

The result of independent t test statistic shows the total average of the treatment group (X AK 1) is 6.00 and the control group (X AK 2) is 1.90 . If the probability value or Sig. (2-tailed) $<0,05$ then hypothesis $\mathrm{H} 0$ is rejected and Ha accepted. In the ttest test obtained Sig. (2-tailed) = $0,000<0,05$ then indicates that $\mathrm{H} 0$ is rejected and $\mathrm{Ha}$ accepted. It proves that there is a difference in the improvement of student learning motivation score between class $\mathrm{X}$ AK 1 as treatment group and class $\mathrm{X}$ AK 2 as control group.

\section{CONCLUSION AND SUGGESTION}

\section{Conclusion}

Based on the research result and discussion it can be inferred that:

a. Development of interactive learning media is conducted through five stages: Analysis, Design, Development, Implementation, and Evaluation

b. The level of feasibility of interactive learning media is examined based on experts judgment (material expert, media expert, and accounting teachers) covering aspects of material, language, learning design, software engineering, and visual communication. Validation results indicate that the interactive learning media as a learning medium is expressed as a Very Feasible category with an average score of 4.5 by a material expert, 4.47 by media expert, and 4.35 by accounting teachers

c. The responses of the students of class XI AK 1 (field trials) on interactive learning media on materials, language, instructional design, software engineering, and visual communication aspects obtained an average value of 4.29 with the category of Very Feasible.

d. Class X AK 1 as treatment group had higher improvement compared to class $\mathrm{X}$ of AK 2 as control group. The treatment motivation improved by $6 \%$. This percentage increase is higher than the control group which only increased by $2 \%$

e. Paired sample t test conducted by each class or group, it can be concluded that the learning media used in each classroom can improve student's learning motivation. However, the average improvement in learning motivation score in class $\mathrm{X} A \mathrm{AK} 1$ 
(treatment group) was 6.3 higher than class X AK 2 (control group) that was 2 .

$\mathrm{f}$. Independent $\mathrm{t}$ test shows the average calculation result of group motivation improvement score (X AK 1) is 6.00 and control group (X AK 2) is 1.90 . There is a significant difference in the learning motivation improvement between class $\mathrm{X}$ AK 1 as treatment group and class $\mathrm{X}$ of $\mathrm{AK} 2$ as control group.

\section{Suggestion}

The researcher realized the limitation of the research. Therefore some suggestions are provided for the relevant parties and further research:

a. School should provide sufficient facilities and infrastructure to support learning activities, such as the addition of an accounting computer laboratory so that several classes can use it simultaneously.

b. School should conduct training activities on the development of learning media for teachers, so they will have sufficient skills to create a variety of learning media.

c. Teacher should use interactive learning media as an alternative to improve student learning motivation.

d. Teacher should explore self-ability to create a variety of learning media from training or learn it independently.

e. Interactive learning media can be developed for a variety of Basic Competencies by considering the suitability of the learning process

f. Field trials of Interactive learning media should be done by using more respondents to get more responses and suggestions, so the learning media become more reliable

g. It is recommended to develop interactive learning media into smart phone (android base) that is more popular for students.

h. Data collection techniques may not only use questionnaires, but also use interviews or observations for better results.

\section{REFERENCES}

Arsyad, A. (2011). Media Pembelajaran. Jakarta: Rajawali Pers.

Efendi, Agus. (2014). The Development of E-Learning Media for The Learning of Vocational Competency Basis in Vocational High Schools. Journal of Education and Practice Volume 5, 22.

Porter, M. E. (1990). Competitive Advantage of Nations. New York: Free Press.

Risnawati, N. (2015). Pengembangan Media Pembelajaran Akuntansi berbentuk Modul Pembelajaran Digital untuk Siswa SMK Negeri 1 Bantul Kelas XI Jurusan Akuntansi pada Materi Pokok Akuntansi Utang. Undergraduate Thesis. Univesitas Negeri Yogyakarta.

Sanjaya, W. (2013). Strategi Pembelajaran Berorientasi Standar Proses Pendidikan. Jakarta: Kencana.

Sardiman, A. M. (2011). Interaksi dan Motivasi Belajar Mengajar. Jakarta: PT. Rajagrafindo.

Sihotang, I. M. (2017). Development on Tutorial Model of Macromedia Flash Program in Preparing Financial Statements. Journal of Education and Practice Volume 8, 17.

Sugiyono. (2015). Metode Penelitian Pendidikan, Pendekatan Kuantitatif, Kualitatif, dan $R \& D$. Bandung: Alfabeta. 
$70-81$

Sukmadinata, Nana Syaodih. (2009). Metode Penelitian Pendidikan. Bandung: PT Remaja Rosdakarya

Sukandi. (2001). Belajar Aktif dan Terpadu. Surabaya: Duta Graha Pustaka.

Warsita, Bambang. (2008). Teknologi Pembelajaran, Landasan dan Aplikasinya. Jakarta: PT. Rineka Cipta. 